\title{
Analysis on Nature in Robert Frost's Poetry
}

\author{
Yuanli Zhang, Wei Ding*, Lixia Jia \\ English Department of Humanities and Social Sciences, Heilongjiang Bayi Agricultural University, Daqing, China
}

Email address:

dingwei0508@gmail.com (Wei Ding)

${ }^{*}$ Corresponding author

\section{To cite this article:}

Yuanli Zhang, Wei Ding, Lixia Jia. Analysis on Nature in Robert Frost's Poetry. English Language, Literature \& Culture. Vol. 2, No. 3, 2017, pp. 25-30. doi: 10.11648/j.ellc.20170203.11

Received: March 21, 2017; Accepted: April 6, 2017; Published: May 17, 2017

\begin{abstract}
Nature is the most distinguished feature in Robert Frost's poems. Frost possesses deep love and sympathy towards nature. However, the typical pastoral life is not the central theme in Frost's poems. Instead, Frost concentrates on the dramatic conflict happened in the natural world. His poems usually begin with an observation in nature and proceed to the connection to human psychological situation. According to Frost, nature is not only the source of pleasure, but also an inspiration for human wisdom. People will get the enlightenment from observation, thus nature becomes a central character in his poetry rather than merely a background.
\end{abstract}

Keywords: Robert Frost, Poetry, Nature

\section{Introduction}

Robert Frost was one of the most widely read poets in the 20th century American literature. Speaking of Frost, people may refer that he was a successful poet who was the only poet ever invited to read his poem at a presidential inauguration. For many people it is an enjoyable experience to read Frost's poems which mostly characterized by nature. For his spending a long life living in the New England countryside, nature easily became his chief subject. Researches on Frost's nature poetry have been various ever since the poet became famous. Some researchers focus on artistic technique of poetry writing while some others show interest in the contents and themes. Besides, some researchers pay more attention on the poet himself----his philosophies. Such researchers help to bring the Frost study to a considerable height. This paper has a discussion on Frost's view on nature, so that we can better understand his nature poems and better appreciate his poetic art. What's more, by delving into Frost's view of nature, we can know more about his nature poems and more about the implications lie behind natural scenes, and learn more about the natural environment around us.

According to Wilcox and Barron, Robert Pinksky, the 1999 poet laureate of the United States, "conducted a yearlong survey of Americans, asking for their favorite poet, and Frost won national poll by a large and impressive margin". It sufficiently demonstrates that Frost is well received in his country, if not the whole world up to now, and "his poetry continues to be a part of an American culture".

In the early 1980s, the Robert Frost Society was founded to perpetuate and encourage the study of his life and work. The founding of the Robert Frost Review in1999 and the first international academic symposium on Frost in 1997 clearly show the study of Frost gains great popularity and draw more and more attention from critics around the world.

The Pastoral Art of Robert Frost by John F. Lynen is well worth reading in its entirety for insight into the use of pastoralism as a poetic device. Lynen's observation of how Frost uses nature in his poetry is particularly useful. [4] In Theory of Literature (Third Edition, 1956), Austin Warren makes a comment on Robert Frost's natural symbolism to show that in most of his poems, there are some natural symbols which are quite difficult for readers to grasp and it is for his natural symbolism that he has drawn a wide audience all over the world [5]. It is true that Frost is keen at the use of natural symbolism, for, nature in the eyes of Robert Frost, according to Robert D. Richardson, is symbolic of spirit. That is to say, when he writes something about nature, he doesn't describe nature purely, instead, he uses natural objects or events as symbols to reveal and express something more profound. George W. Nitchie, in "The World of Nature" collected in Human Values in the Poetry of Robert Frost, comments on Frost's view of nature, observing that Frost's 
values and view of nature are intimately related. [6] Robert W. French reveals in Robert Frost and the Darkness of Nature that there is impenetrable barrier between man and nature. [7]

\section{Robert Frost and His View on Nature}

Robert Lee Frost (1874-1963) had widely been received in American, who received the Pulitzer Prize four times, and was the only poet ever invited to read his poem at a presidential inauguration.

Born in San Francisco, Robert Lee Frost was named after the defeated Confederate general Robert E. Lee. After the death of his father, the rebellious son of a prudent, hard-working, successful Massachusetts farmer, he moved with his mother and sister to eastern Massachusetts near his paternal grandparents.

Deeply influenced by his experience in his young, Robert Frost had a unique position in modern poetry. He has been widely received by audience while his poetry does not receive careful critical judgment. This neglect is due much to the nature of his poetry. His poetry seems to lack the complexity one expects to find at the center of the best modern verse. His verse form is traditional, his sentences are always clear, and his language is often close to every day speech. His simplicity makes many readers' exploration stop here. Besides, nature is frequently used in his poetry. Frost denied being a nature poet. "I'm not a nature poet," he once declared, "there is almost always a person in my poems." [3]

\subsection{Robert Frost's Nature Poetry}

Robert Frost was the leading modern American poet of nature and rural life. Most of his poems are upon natural element. He was very much interested in natural things; he found beauty in common place. Although he has a keen understanding of natural world, Frost does not aim at presenting natural scenery and charming rural life. His poems are concerned with human psychological condition. Robert Once said, "some people call me poet for nature because of the natural setting. But I am not a poet for nature, there is also something else in my poems." [3] Robert Frost uses nature as a background to illustrate people's psychological struggle with everyday life. His poems usually begin with an observation in nature and proceed to the connection to human situation, such as loneliness, helplessness, confusion, and indifferent human relationship.

Nature is the most distinguished feature in Robert Frost's poems. Frost possesses deep love and sympathy towards nature which is the source for inspiration. He used to wander in the woods with his kids, and looked into the starry sky before sleep, from which he got the spiritual meaning out of nature. However, the typical pastoral life is not the central theme in Frost's poems. Instead, Frost concentrates on the dramatic conflict happened in the natural world, such as the confusion and dilemma in life (as in "Mending Wall"), and the danger of nature (as in "Exposed Nest"). According to Frost, nature is not only the source of pleasure, but also an inspiration for human wisdom. People will get the enlightenment from observation (as in the "Birches"). Nature becomes a central character in his poetry rather than merely a background.

Nature is employed as a metaphor in Frost's poems. He describes the natural object and leads the reader to a comparison. Frost's poems are easy and precise in the literal level, since his observation is accurate. However, he is not going to record the natural world. He is making an analogy to some human condition through telling the nature stories. Though he never forces his idea on the reader, he hopes the reader is close to it. Frost's poetry is rooted in his psychological concern and expressed through a material embodiment with a natural background. Frost uses to spend time to depict it sensitively and carefully, using skillful poetic and figurative language. His poems serve as good examples to study the use of images and poetic skills.

\subsection{Robert Frost's View on Nature}

Before we come to discuss Frost's nature poetry, two figures must be mentioned here: Wordsworth and Emerson. As we know both of them are famous for their view on nature. The reader's attitude toward nature is well determined by the lake poets and their English successors. Wordsworth is a pantheist who believes that God exists everywhere in nature. According to him, nature is in harmony with mankind, nature and man are in the spiritual union. Emerson highlights his view on nature in his book, Nature (1836). Similar to Wordsworth, he believes in the immanence of God in nature. Nature in Emerson's eyes is symbolic of spirit.

In many a poem of Frost, we know that Frost shares with Wordsworth and Emerson a keen interest in nature. But Frost's perception of nature is more complicated than theirs.

\subsubsection{The Bright Side of Nature}

In Frost's poetry, there exist bright side of nature. In my poems, we read the poet's delight in nature----his trees, grass, and animals are described with such affection; his characters are full of such happiness. His nature is filled with beauty and benevolence. We can fully feel the poet's affection to nature's beauty and grace.

"A Winter Eden" can serve as a good example of nature's beauty. Look at the following stanzas:

A winter garden in an alder swamp, Where conies now come out to sun and romp, As near a paradise as it can be And not melt snow or start a dormant tree. It lifts existence on a plane of snow One level higher than the earth below, One level nearer heaven overhead, And last year's berries shining scarlet red. It lifts a gaunt luxuriating beast Where he can stretch and hold his highest feat On some wild apple tree's young tender bark, What well may prove the year's high girdle mark. So near to paradise all pairing ends: Here loveless birds now flock as winter friends, Content with bud-inspecting. They presume To say which buds are leaf and which are bloom. A feather-hammer gives a double knock This Eden day is done at two o'clock. An hour of winter day might seem too short To make it worth life's while to wake and sport. 
This poem is about the place of winter in the cycle of the seasons, and how winter symbolizes the point in the cycle of life that marks the transition to rebirth. We may find beauty in the snowy woods or have your mood lifted by the song of a bird. Contrary to popular belief in winter as cold, death and bleakness, in this poem Frost shows us a beautiful, delight and lively scene. The winter garden, although "on a plane of snow", is attractive with "last year's berries shining scarlet red". The animals in the garden are active with their respective tricks. The birds flock as friends. This is really a lovely and cheerful scene, a Winter Eden, as Frost suggests by the title.

Nature as a benevolent being is not only capable of pleasing, but also comforting man. Let's look at another Frost's poem, "Tree at My Window":

Tree at my window, window tree, My sash is lowered when night comes on; But let there never be curtain drawn Between you and me.

Vague dream head lifted out of the ground, And thing next most diffuse to cloud, Not all your light tongues talking aloud Could be profound.

But tree, I have seen you taken and tossed, And if you have seen me when I slept, You have seen me when I was taken and swept And all but lost.

That day she put our heads together, Fate had her imagination about her, Your head so much concerned with outer, Mine with inner, weather.

The poet makes a comparison between himself and the tree out of the window. Although he will draw the curtain at night, he hopes that there will always see each other and be intimate friends. The branches of the tree look like a "vague" head wavering in the wind. The rustle of the leaves could be meaningless talks and make no sense to the poets. However, the poet has seen the tree tossed in the storms, and the tree has also witnessed the poet swept by the storm in his dreams. The poet's fate is closely connected with the tree's, and they share a deep sympathy with each other who struggle against their own troubles. The poet feels that they are companions-- the tree is standing up in the natural weather, and the poet is standing up in his inner weather.

By now we have read some poems by which Frost extols nature at its beat, is the embodiment of both beauty and benevolence. Yet these only constitute one side of Frost's view on nature. There is always the other side.

\subsubsection{The Dark Side of Nature}

Lionel Trilling defined Frost as a "terrifying poet" who depicted a "terrifying universe" [7] at a dinner party celebrating Frost's eighty-fifth birthday. Trilling's speech made many critics re-examined Frost's poetry, which they once thought bright and optimistic. In fact, the "dark" quality in Frost's poetry is so conspicuous that it will by no means escape our eyes. [12]

The "dark" quality brings about the dark side of nature in Frost's poetry. The word "dark", in its various forms, often occurs in Frost's nature poetry. "Into My Own", the first poem in Frost's first book, A Boy's Will, begins:

One of my wishes is that those dark trees, So old and firm they scarcely show the breeze, Were not, as'twere, the merest mask of gloom, But stretched away unto the edge of doom.

Increasingly enough, we see the transition of tree imagery run throughout Frost's poetry. "Dark trees" become "dark woods" in "The Onset":

Always the same, when on a fated night At last the gathered snow lets down as white As may be in dark woods, and with a song It shall not make again all winter long...

Then in "Come In", the woods become the "pillared dark" from which a thrush's bewitching singing is heard:

Far in the pillared dark

Thrush music went----

Almost like a call to come in

To the dark and lament

Darkness is usually suggestive of mystery, ill omen and terror. The poem shows the poet as he stands by the edge of the woods, listening to the song of an unknown bird. The song of the bird is fascinating and lures the poet step in the dark woods. But he resists the temptation and does not come in. What keeps him off the woods is their darkness.

So is nature in Frost's poetry, dual-charactered, namely, bright and dark. It can be a friend of man, but a hostile friend at times. It can also be an enemy, but a generous one from time to time.

\section{Nature as a Source of Human Wisdom}

"How many times it thundered before Franklin took the hint. How many apples fell on Newton's head before he took the hint. Nature is always hinting at us. It hints over and over again. And suddenly we take the hint."----Robert Frost

Nature is always a hint to us. It hints all the time until we suddenly see the light. Franklin took the hint of thunder and invented lightening rod. Newton took the hint of a falling apple and developed the Law of Universal Gravity. Each of us benefits from nature. We take hints from nature and strengthen our knowledge. We may not become giants like Franklin and Newton, but we can become wiser persons. Nature is a source of human wisdom.

\subsection{Close Relationship between Man and Nature}

Man and nature are closely related. We can not live without nature, even if we live all our lives in a large city. In a sense, human beings are part of nature. We are governed like the other creatures by the same rules in nature.

In Frost's poetry man and nature, and nature and man are counter-parts of each other. [9] We cannot separate one from the other. He makes nature as a medium, describe nature in all its beauty, loveliness and even meanness, but ultimately the journey of each poem ends in the problems of man and solution of this problem in human psychology. The poems of Frost in which, he takes up, the theme of contraries have a universal import. In these poems, the persona poet is not an individual but a type of all human beings who are obliged to live life in the midst of nature to earn their livelihood but livelihood is not their only aim. May be, they are farmers but they are educated farmers, thinking human beings with whom 
finding a solution to their problems is as important as their living. Since they think intensively and extensively to find a solution of their problems, thinking becomes with them an infinite process. The more they think, the more they learn until they feel that learning is an endless process. Therefore, so long as man is thinking, and he will think forever, the poetry of Frost will remain expose relationship between man and nature.

\subsection{Symbolic Quality of Nature}

Symbolism is the use of one object or action (a symbol) to represent or suggest something else. [14] It is a prevalent use for poets to express their ideas through indirect statements, thus invest the object with an implied meaning. Thus symbolism means a veiled mode of communication. A poem may have a surface meaning but it may also have a deeper meaning which is understood by the reader only by interpreting the deeper significance of the words and phrases used. [15] Frost's poetry always presents the general through a particular scene.

"After Apple Picking" is an good example of Frost's symbolic poem. The poem is a description of the speaker feeling tired after picking up a large amount of apples from his orchard tree. The act of harvesting apples is a symbol for the daily work in life. Afterwards, the speaker reveals his insight as:

"Essence of winter sleep is on the night,

The scene of apples: I am drowsing off."

The speaker is aware of the coming winter after the harvesting autumn. On the literal level, it is a natural circle for the change of the seasons, and sleep is what one must get during the night. On the deeper meaning, winter is a symbol for death. The speaker knows that he is getting old, and death is a natural ending for him. After accomplishing the task in life, the speaker feels that he is drowsing off, which indicates that he is ready for death.

Frost's poetic language is simple and the natural world in his poems are as true as he sees it. However, the meaning he expressed is significant, which can only be achieved through a symbolic reading.

\section{3. “From Delight to Wisdom”: Nature's Inspiration to Frost}

"It (a poem) begins in delight, it inclines to the impulse, it assumes direction with the first line laid down, it runs a course of lucky events, and ends in a clarification of life----not necessarily a great clarification, such as sects and cults are founded on, but in a momentary stay against confusion." ----Robert Frost

This quotation is Frost's famous dictum on how a poem works. It is well known that Robert Frost, in a foreword to his Collected Poems (1939), wrote: a poem "begins in delight and ends in wisdom." [8] Here the word "delight" does not necessarily take its literal meaning of joy, but the wonder at some unexpected sight. Often Frost is seen to begin a poem with the "delight" of observing a particular natural scene; but gradually he turns to meditation on the implication of the natural scene; and finally he ends his poem with the "wisdom" of an insight into the human situations. Nature, to Frost, is an inspiration.

Frost's poem, "The Pasture", which Frost included at the beginning of every collection of his poetry, can be a good example of his expressive and commonsense style as well as the source of delight and wisdom. The village farmer who is the "persona" of the poem plainly talks about his daily activities with a sense on delight narrating at the same time the delightful bucolic atmosphere in the sight of "pasture spring" and a "little calf" tottering beside its mother. But each stanza ends with wisdom, which actually means, deep understanding of life, expressing the limitations of human life: "I sha'nt be gone long". The farmer enjoys his life with simple activities within the domain of his farm though he cannot go beyond:

I'm going out to clean the pasture spring;

I'll only stop to rake the leaves away

(And wait to watch the water clear, I may):

I sha'n't be gone long.----You come too.

I'm going out to fetch the little calf

That's standing by the mother. It's so young,

It totters when she licks it with her tongue.

I sha'n't be gone long.----You come too.

The farmer expresses his delight inviting others; "You come too". The commonsense simplicity of verse, along with deep philosophy of life, creates a sense of delight and wisdom for readers.

Frost's wisdom has been well recognized. He is referred to as a farmer sage, a shrewd poet, a man of insight, and a powerful seer who sees what others don't see. It is obvious that Frost's wisdom comes largely from his communication with nature. If he denies being "a nature poet", as we have seen him declare earlier in his paper, he would not possibly deny being a poet who is constantly inspired by nature.

\section{The Implications of Robert Frost's View on Nature}

People love Robert Frost's poems because they can always learn something about life by reading them. Specifically, the implications of Robert Frost's view on nature can be shown from the reading of his poems. In this part, I shall take a step further to explore the implications of Frost's view on nature.

\subsection{Dialectical Mind to View Nature}

The first implication I study here is that nature demands man a dialectical mind towards itself. In other words, we should hold a dialectical mind if we are to treat nature properly. This is decided by nature's dual character.

In 2.2, we have discussed about Frost's view on nature, namely, nature has two sides----the bright side and the dark side. These two sides are opposed to each other, but they can not be separated from each other. To hold a dialectical mind to view nature, we must enumerate both sides. We should know that there is no clear dividing line for good and evil in nature. 
A scene of snow-covered land is beautiful because of its purity and tranquility, but there is the treat of chill and desolation.

Such mind to view nature is one of dialectic. It is different from either the Romantic way or the post-Darwinian way of treating nature. The Romantics have a tendency to overestimate nature's love and benevolence. When they come to realize the transience of beauty and the harshness of reality, they often become sad and disillusioned. We can see examples of this in Wordsworth and Emerson, who both sang high praise of nature's beauty and benevolence in their early poetry, but both turned gloomy in their late years with the recognition of nature's evil [10]. The post-Darwinian nature poets, those who are influenced deeply by Darwin's theory of evolution, are always too gloomy. They emphasize the coldness of nature ad the helplessness of man before the grim facts of nature. In Hardy's nature lyrics, we often see the bleakness of landscape, coupled with the tragedies of those withered flowers and frustrated people. While Frost's way of treating nature is different from both the Romantic and the post-Darwinian poets. He is an intermediary between the two. He can enjoy nature's beauty, but he is always aware of nature's terror. Frost takes efforts to juxtapose good and evil in nature. To treat nature properly, we should hold a dialectical mind.

\subsection{Nature as a Book}

A second implication I study here is that nature should be read as a book. We might not forget Frost's metaphor of nature as a book, as is shown in "The mountain he was climbing had the slant/ As of a book held up before his eyes/ (And was a text albeit done in plant)." [11] The mountain here represents nature, so nature is like a book held up before man's eyes. [13] What lies behind this metaphor is Frost's recognition of nature's symbolic quality. Nature is full of symbols. Each symbol is endowed with a certain meaning for mankind. With such symbols, nature can be read and analyzed just as a text. As we know, Frost spends much of his time with nature. His contact with nature is in evidence his "outdoor schooling", which is as important to him as the "indoor schooling". [1]

Instead of written words, the book is done in vivid pictures: rustling trees, great mountains, the sunshine, a rainfall... All these pictures are dynamic and capable of exciting our sense organs. More importantly, they are symbolic. A sweet red rose can be a symbol of love; a heavy storm is sometimes symbolic of power, but sometimes destruction... We see nature as a book in vivid images and rich meanings. It is symbolic and instructive to mankind, and a source of human wisdom.

Nature as a book, is accessible to everyone, but it is not always an easy book for us. The meanings in it are never stated but implied. Besides, it is dynamic and uncertain. To be good readers, we have to be observant, and we have to think and do analysis. Frost sets a good example to us in this aspect. He is a remarkable reader of nature who reads and thinks and always learns. What's more, he is always trying to share with us what he has learned. Frost expects us to see what he has seen, and learn what he has learned. More importantly, he inspires us to read and analyze nature as a book.

\section{Conclusion}

Robert Frost is beyond doubt a unique poet in modern American literature. One element that accounts for his uniqueness is the use of nature in his poetry. Frost denies being a nature poet, but he seems never tired of using nature in his poetry. He has written a large number of nature poems throughout his career. Nature is used in his poems for different purposes: it is sometimes the setting, sometimes the theme, and sometimes a metaphor for a certain human situation. People love his poems for his clever use of nature, but they do not pay much attention to the poet's view on nature that lies behind his poetry.

As a matter of fact, Frost's view on nature is an important part of his heritage to us. It helps with our understanding of Frost's poetry. What's more, it provides us with valuable insight into the natural world around us. So it deserves to be studied. Nature is a source of human wisdom. There is a wealth in nature, and nature is, as Frost says, "always hinting at us" [2]. Frost believes that there is close relationship between man and nature. We can not live without nature and we are governed like the other creatures by the same rules in nature. He also believes in the symbolic quality of nature. In many of his nature poems, he depicts nature as symbolic of the human world. He often begins a poem with the "delight" in nature, and ends it with the "wisdom" that evokes on man.

Frost's views on nature are important implications for us. On account of nature's dual character, we need to hold a dialectical mind towards it. We should juxtapose contradictory elements in nature, and then treat nature reasonably. A second implication is that we should read and analyze nature as a book, because nature is a source of wisdom.

\section{Acknowledgments}

This work was supported by Program for Humanities and Social Sciences of Heilongjiang Province (15WWE05), Study on the Change of Themes in Robert Frost's Poetry.

\section{References}

[1] Lawrence Thompson. Robert Frost: The Early Years, 1874-1915. Henry Holt \& Company, Inc, 1966.

[2] Lawrence Thompson. Robert Frost: The Years of Triumph, 1915-1938. New York: Holt, Rinehart \& Winston, 1970.

[3] Lawrence Thompson. Robert Frost: The Later Years, 1938-1963. Henry Holt \& Company, Inc, 1977.

[4] John F. Lynen. The Pastoral Art of Robert Frost. Yale University Press, 1960.

[5] Rene Wellek \& Austin Warren. Theory of Literature. Peregrine Books, 1985, pp190.

[6] George W. Nitchie. Human Values in the Poetry of Robert Frost. Gordian Press, 1978.

[7] French, Warren, (ed.). Twentieth-Century American literature. London: The Macmillan Press Limited, 1980, 218-219. 
[8] Robert Frost. Collected Poems. Henry Holt \& Company, Inc, 1939.

[9] Gerber, Philip 1. (ed.). Critical Essays on Robert Frost. Boston: G. K. Hall \& Company, 1982.

[10] Richardson, Robert D. (ed.). Ralph Waldo Emerson: Selected Essays, Lectures, and Poems. New York: Bantam Books, 1990.

[11] Moore, Marianne. "Book Review: The Poetry of Robert Frost: Constellations of Intention Reuben A. Brower", Modern Philology, 1964.

[12] Marit J. MacArthur. "The American Landscape in the Poetry of
Frost, Bishop, and Ashbery: The House Abandoned", Bakingstoke: Palgrave Macmillan, 2008.

[13] Muldoon, Paul. The End of the Poem: "The Mountain" by Robert Frost. American Poetry Review, 2001, 30(1):41-46.

[14] Richard Nordquist. Symbolism - Glossary of Grammatical and Rhetorical Terms, Available:

https://www.thoughtco.com/symbolism-definition-1692169, Oct 27, 2016.

[15] Symbols in Robert Frost's poems. Available: http:// http://www.josbd.com/symbols-in-robert-frosts-poems, March $22,2017$. 